\title{
The Relationship between Multidimensional Narcissism, Explicit and Implicit Self-Esteem in Eating Disorders
}

\author{
Katrine Boucher1, Catherine Bégin'1, Marie-Pierre Gagnon-Girouard ${ }^{2}$, Carole Ratté ${ }^{3}$ \\ ${ }^{1}$ School of Psychology, Laval University, Quebec City, Canada \\ ${ }^{2}$ School of Psychology, Université du Québec à Trois-Rivières (UQTR), Trois-Rivières, Canada \\ ${ }^{3}$ Eating Disorders Unit, Laval University Medical Centre (CHUL), Quebec City, Canada \\ Email: Catherine.begin@psy.ulaval.ca
}

Received 23 November 2015; accepted 25 December 2015; published 28 December 2015

Copyright (C) 2015 by authors and Scientific Research Publishing Inc.

This work is licensed under the Creative Commons Attribution International License (CC BY). http://creativecommons.org/licenses/by/4.0/

(c) (i) Open Access

\section{Abstract}

Eating disorders (EDs) are often characterised by a low self-esteem. Further examination of the different facets of self-esteem (explicit and implicit) and its relationship to a key personality trait, narcissism, might deepen our understanding of EDs. The aim of the present study is to examine the relationship between explicit and implicit self-esteem as well as grandiose and vulnerable narcissism in a population with EDs. Explicit and implicit self-esteem as well as pathological narcissism were compared in participants with EDs $(n=69)$, participants with anxiety disorders $(n=$ 51) and participants with no history of psychiatric disorders $(n=93)$. All participants completed a battery of questionnaires and participated in a categorization task to measure implicit self-esteem, the Implicit Association Test (IAT). The participants with EDs had the lowest explicit self-esteem $(p<0.001)$, the highest levels of vulnerable narcissism $(p<0.001)$ and they presented higher levels of grandiose narcissism compared to participants with no history of psychiatric disorders. However, they were not different than the other groups on implicit self-esteem $(p=0.271)$. Participants with EDs are characterised by a low convergent self-esteem (low explicit and implicit self-esteem). Our findings also suggest that participants with EDs present narcissistic fragilities that are better explained by explicit self-esteem alone rather than by implicit self-esteem or an interaction of both facets of self-esteem.

\section{Keywords}

Pathological Narcissism, Explicit Self-Esteem, Implicit Self-Esteem, Eating Disorders, Implicit Association Test 


\section{Introduction}

Narcissism refers to an inflated sense of self, generally associated with vanity, grandiosity, and a sense of entitlement (Horowitz, 2013). Individuals with high levels of narcissism express highly positive self-views and engage in self-enhancement strategies (Horvath \& Morf, 2010). However, psychodynamic theorists proposed that beneath these feelings of superiority and grandiosity, individuals with high levels of narcissism hid deep-seated negative feelings towards their self (Akhtar \& Thomson, 1982; Kernberg, 1966, 1975; Kohut \& Wolf, 1986). This is called the "mask model of narcissism", a model that is originated from clinical observations.

To validate the mask model of narcissism, social and personality researchers examine explicit and implicit levels of self-esteem in order to identify how individuals with narcissism really feel about themselves, i.e. inside and out. Explicit self-esteem refers to a more rational, conscious and effortful facet of self-esteem and is assessed with self-report measures. Implicit self-esteem is defined as a more automatic, intuitive and effortless facet of self-esteem and is measured by implicit measures like the Implicit Association Task (IAT; Greenwald and Farnham, 2000). According to the mask model, narcissism should be associated with a high level of explicit self-esteem and a low level of implicit self-esteem, which refers to a discrepant high self-esteem (Jordan, Spencer, Zanna, Hoshino-Browne, \& Correll, 2003).

\subsection{Narcissism and Self-Esteem in General Population}

Among the general population, the relationship between narcissism and the two facets of self-esteem is unclear. Whereas some studies showed that individuals with high levels of narcissism present discrepant high self-esteem (i.e. high explicit and low implicit self-esteem) as proposed by the mask model (Brown \& Bosson, 2001; Jordan, Spencer, Zanna, Hoshino-Browne, \& Correll, 2003; Zeigler-Hill, 2006), others did not replicate these results (e.g., Bosson \& Prewitt-Freilino, 2007; Campbell, Bosson, Goheen, Lakey, \& Kernis, 2007). Furthermore, Bosson and her colleagues (2008), in a meta-analysis with published and unpublished data, found no relationship between narcissism and implicit self-esteem as well as no interaction effect between explicit and implicit selfesteem when predicting narcissism, thus refuting the mask model of narcissism (Bosson, Lakey, Campbell, Zeigler-Hill, Jordan, \& Kernis, 2008). Similarly, Gregg and Sedikides (2010) found no interaction effect to predict narcissism, but underlined that low implicit self-esteem was systematically associated with higher narcissism, thus supporting that implicit self-esteem could be an overall index for ego fragility among the general population.

\subsection{Narcissism and Self-Esteem in Psychiatric Population}

To our knowledge, only one study was conducted among individuals with psychiatric disorders to assess the relationship between narcissism and the two facets of self-esteem (Vater, Ritter, Schröder-Abé, Schütz, Lammers, Bosson et al., 2013). This study compared patients with narcissistic personality disorder, patients with borderline personality disorder and healthy controls. In the group of individuals with narcissistic personality disorder, discrepant low self-esteem (i.e. low explicit and high implicit self-esteem) predicted higher narcissism scores (Vater et al., 2013). Although, these results are different from what was originally postulated with the mask model of narcissism (discrepant high self-esteem, i.e. high explicit and low implicit self-esteem), they highlight a discrepant self-esteem when predicting narcissism. Furthermore, those results are in conformity with studies on explicit self-esteem among psychiatric populations, which demonstrates that psychiatric populations exhibit lower explicit self-esteem than healthy controls. Findings on implicit self-esteem are less clear among psychiatric population. Some results showed high levels of implicit self-esteem (De Jong, 2002; Gemar, Segal, Sagrati, \& Kennedy, 2001; De Raedt, Schacht, Franck, \& De Houwer, 2006), while others rather found low levels of implicit self-esteem, invalidating the discrepancy between the two facets of self-esteem (Buhlmann, Teachman, Gerbershagen, Kikul, \& Rief, 2008; Risch, Buba, Birk, Morina, Steffens, \& Stangier, 2010).

\subsection{Narcissism and Self-Esteem in EDs}

EDs appear to be of significant interest to explore the relationship between self-esteem and narcissism considering that 1) ED patients present higher levels of narcissism than healthy controls and other psychiatric populations (Lehoux, Steiger, \& Jabalpurlawa, 2000; Steiger, Jabalpurwala, Champagne, \& Stotland, 1997) and that 2) specific eating behaviours and attitudes are linked to narcissism, (Brunton, Lacey, \& Waller, 2005; Gordon \& 
Dombeck, 2010), particularly vulnerable narcissism (Cambpell \& Waller, 2009; Waller, Sines, Meyer, Foster, \& Skelton, 2007). Furthermore, narcissism persists over time, even when ED patients are in full remission (Holliday, Landau, \& Treasure, 2006). Therefore, the study of ED patients might enlighten our understanding of narcissism.

Accordingly, Steiger and his colleagues (1997) proposed that the narcissistic overinvestment of body image and eating behaviours among women with EDs might be an attempt to stabilize self-image. However, despite high levels of narcissism, which might reflect self-love and confidence, EDs are also characterized by low explicit self-esteem and social avoidance. Indeed, low explicit self-esteem has been well documented in EDs (Fairburn, Cooper, \& Shafran, 2003; Jacobi, Hayward, de Zwaan, Kraemer, \& Agras, 2004; Meijboom, Jensen, Kampman, \& Schouten, 1999). However, research on implicit self-esteem among EDs is scarce and contradictory. Vanderlinden and his colleagues (2009) found that ED patients had lower implicit self-esteem than healthy controls, whereas Cockerham and her colleagues (2009) found that women with bulimia nervosa and binge eating disorder had higher implicit self-esteem than a control group. Whether ED patients are characterized by a low discrepant self-esteem expressed by low explicit self-esteem and high implicit self-esteem or a low convergent self-esteem expressed by both lower levels of explicit and implicit self-esteem is still unclear.

Some methodological factors might explain those ambiguous results and the difficulty to capture the discrepancy in self-esteem when predicting narcissism. Among them, the reliability of the measure of the narcissism should be questioned. Up until now, studies conducted have referred to a self-report questionnaire, the Narcissistic Personality Inventory (NPI; Raskin \& Hall, 1979, 1981). This well-validated instrument, however, does not measure pathological narcissism and is not a multidimensional measure. There are some evidences suggesting that pathological narcissism is a complex and dynamic process that cannot be studied as a one-dimensional and general construct. Two phenotypes, grandiose and vulnerable narcissism, although described with varying terminology, have consistently emerged from the literature over the past years (Pincus et al., 2010). Grandiose narcissism refers to aggression and dominance, whereas vulnerable narcissism is related to a more defensive and insecure grandiosity, which reflects inadequacy, incompetence and negative affect (Miller, Hoffman, Gaughan, Gentile, Maples, \& Campbell, 2011). In specifying the construct of narcissism by distinguishing its associated phenotypes, it could certainly help refine our understanding of the complex relationship between self-esteem and pathological narcissism.

The present study is the first one that intends to explore the association between both facets of self-esteem and the two dimensions of pathological narcissism (grandiose and vulnerable narcissism). Our first objective is to compare levels of pathological narcissism and the two facets of self-esteem between a group of women who suffer from eating disorders (EDs), a psychiatric control group composed of women who suffer from anxiety disorders (ANX) and a healthy control group of women with no psychiatric disorders (HC) using a multidimensional measure of narcissism. The presence of a psychiatric control group allow us to determine whether the differences potentially observed are attributable to EDs pathology specifically or to general psychopathology. Our second objective is to explore the role of explicit and implicit self-esteem in predicting grandiose and vulnerable narcissism. This allows us to determine whether a low discrepant (low explicit self-esteem and high implicit self-esteem) or a low convergent (low explicit self-esteem and low implicit self-esteem) model of self-esteem is more appropriate when predicting vulnerable and grandiose narcissism among EDs.

\section{Methods}

\subsection{Participants}

For the ED group, 69 women, aged between 19 and 55 years old (mean age $=26.77$, SD $=8.12$ ), were recruited through the Eating Disorders Unit at Laval University Medical Centre in Quebec City, Canada. To participate in the study, women had to meet the diagnostic criteria for Anorexia Nervosa (AN) $(n=27)$, Bulimia $(B N)(n=$ 28), or Eating Disorders Not Otherwise Specified (EDNOS) $(n=14)$, as described in the DSM-IV-TR. According to the psychiatric evaluation made by the psychiatrist at the Eating Disorders Unit, 20 ED patients suffered from generalized anxiety disorder, 8 from obsessive-compulsive disorder, 6 from panic disorder with or without agoraphobia, 6 from social phobia, 5 from unspecified anxiety disorder, and 4 from posttraumatic stress disorder. Participants were excluded if they showed psychotic symptoms. Since no significant differences were found between ED diagnoses in term of explicit self-esteem $(p=0.28)$, implicit self-esteem $(p=0.40)$ and levels of grandiose narcissism $(p=0.60)$ and vulnerable narcissism $(p=0.83)$, the ED group was treated as a single 
transdiagnostic sample.

For the ANX group, 51 women, aged between 19 and 55 years old (mean age $=26.9$, SD $=8.2$ ) were recruited through the email list of students and employees at Laval University in Quebec City, Canada. To participate in the study, women had to have received a current diagnosis of anxiety disorder by their physician or another health professional. The PhD student in charge of the experiment used the Mini-International Neuropsychiatric Interview (MINI) in order to confirm the anxiety disorder diagnosis and to ensure the absence of an eating disorder. Considering that women in this group may have more than one diagnosis among anxiety disorders, thirty-eight women suffered from panic disorder with or without agoraphobia, 18 from generalised anxiety disorder, 7 from social phobia, 6 from obsessive-compulsive disorder, 3 from agoraphobia without panic disorder and 3 from posttraumatic stress disorder. Psychological or pharmacological treatments for anxiety disorders as well as the presence of a mood disorder were not exclusion criteria. Participants were excluded if they met the criteria for EDs or psychotic disorders.

For the HC group, 93 women, aged between 19 and 50 years old (mean age $=24.71$, SD $=6.55$ ) were recruited through the email list of students and employees of Laval University. To participate in the study, women could not suffer from EDs, anxiety disorders, mood disorders or psychotic disorders. Four participants were excluded from the study because they were older than 55 years old and two others were also excluded because they showed significant pathological eating behaviours.

Table 1 presents sociodemographic information for the three groups. There were no significant differences between the three groups of participants on age, marital status, ethnicity, and income ( $p$ between 0.06 and 0.76 ), but they differed with regards to academic level $(p=0.022)$. More women in the HC group were undergraduate students while more women in the ANX and the ED groups completed their bachelor's degree and so, they were doing or completing graduate study (doing a master's or a doctoral degree).

\subsection{Procedure}

After their first psychiatric evaluation session at the Eating Disorders Unit at Laval University Medical Centre, a research assistant explained to ED patients the general aim of the research project, which was to clarify the link between personality traits and eating pathology. No information was given on the fact that explicit and implicit self-esteem would be under examination. ED patients were informed that they would get more information after the experiment. If they agreed, they signed an informed consent form approved by the ethic committee of Laval University Medical Centre, then completed the questionnaires and participated in the categorization task, i.e. Implicit Association Test (IAT). ED patients were left alone in a room with minimal stimuli. After the completion of the IAT, the research assistant revealed the complete objectives of the study (debriefing), which were to examine the associations between narcissism and explicit and implicit self-esteem and it was explained to them that the categorization task was in fact a measure of implicit self-esteem.

Participants of the ANX group and the HC group received an invitation to the research project by email and volunteers contacted the research team. Participants were met individually at the Psychological Clinic of Laval University in Quebec City. The same procedure of the ED group was applied to these two groups except that a structured interview was conducted to confirm inclusion and exclusion diagnostic criteria (which were different according to group pertaining, see participants section).

\subsection{Measures}

\subsubsection{Inclusion and Exclusion Criteria}

The French translation of the Mini-International Neuropsychiatric Interview (MINI), a short semi-structured diagnostic interview based on the DSM-IV was used (Sheehan, Lecrubier, Sheehan, Amorim, Janavs, Weiller et al., 1998). The mood disorders, anxiety disorders, eating disorders and psychotic disorders modules were selected for the purpose of the research project. The MINI showed a good concordance with the Structured Clinical Interview for DSM Disorders (SCID) in a clinical population (kappa values from 0.50 to 0.90 ) (Sheehan, Lecrubier, Sheehan, Amorim, Janavs, Weiller et al., 1998). Kappa values were all above 0.75 showing that the MINI has an excellent interrater reliability. The depressive disorders, anxiety disorders, eating disorders and psychotic disorder modules showed very good retest reliability (kappa values from 0.52 to 1.00 ).

\subsubsection{Socio-Demographic Data}

Participants' socio-demographic characteristics were assessed with a home questionnaire including questions 
Table 1. Sociodemographic information about the three groups.

\begin{tabular}{|c|c|c|c|c|}
\hline \multirow[b]{2}{*}{ Variables } & & \multicolumn{3}{|c|}{ Groups } \\
\hline & & $\begin{array}{c}\text { EDs }(\mathrm{n}=69) \\
\%\end{array}$ & $\begin{array}{c}\text { ANX }(\mathrm{n}=51) \\
\%\end{array}$ & $\begin{array}{c}\mathrm{HC}(\mathrm{n}=93) \\
\%\end{array}$ \\
\hline \multirow{4}{*}{ Marital Status } & Single & 55.7 & 58.8 & 67.7 \\
\hline & Civil union & 39.3 & 31.4 & 21.5 \\
\hline & Married & 1.6 & 7.8 & 8.6 \\
\hline & Separated/Divorced & 3.3 & 2.0 & 2.2 \\
\hline \multirow{4}{*}{ Family status } & Single with no children & 47.5 & 35.3 & 50.5 \\
\hline & Single with children & 1.6 & 3.9 & 1.1 \\
\hline & In a relationship with no children & 39.3 & 52.9 & 40.9 \\
\hline & In a relationship with children & 11.5 & 7.8 & 7.5 \\
\hline \multirow{4}{*}{ Ethnicity } & Caucasian & 96.7 & 100 & 92.4 \\
\hline & Asian & 1.6 & 0 & 2.2 \\
\hline & African-American & 0 & 0 & 1.1 \\
\hline & Other & 1.6 & 0 & 3.3 \\
\hline \multirow{3}{*}{ Citizenship } & Prefer not to answer & 0 & 0 & 1.1 \\
\hline & Canadian & 100 & 98 & 91.4 \\
\hline & French & 0 & 2 & 8.6 \\
\hline \multirow{6}{*}{ Occupation } & Student & 37.7 & 76.5 & 76.3 \\
\hline & Working full time & 36.1 & 17.6 & 16.1 \\
\hline & Working part time & 3.3 & 5.9 & 6.5 \\
\hline & On leave & 16.4 & 0 & 1.1 \\
\hline & Welfare & 4.9 & 0 & 0 \\
\hline & Working at home & 1.6 & 0 & 0 \\
\hline \multirow{6}{*}{ Level of education } & High school diploma & 13.1 & 2 & 3.2 \\
\hline & Diploma of professional studies & 8.2 & 0 & 2.2 \\
\hline & College degree & 42.7 & 51 & 57 \\
\hline & Bachelor degree & 27.9 & 25.5 & 21.5 \\
\hline & Postgraduate degree & 5 & 2 & 16.2 \\
\hline & Other & 0 & 3.9 & 0 \\
\hline \multirow{7}{*}{ Revenue } & $0-19,999 \$$ & 53.3 & 66.7 & 75.3 \\
\hline & $20,000-39,999 \$$ & 18.3 & 25.5 & 9.7 \\
\hline & $40,000-59,999 \$$ & 13.3 & 2.0 & 8.6 \\
\hline & $60,000-79,999 \$$ & 11.7 & 3.9 & 2.2 \\
\hline & $80,000-99,999 \$$ & 0 & 0 & 2.2 \\
\hline & 100,000 and more & 1.7 & 2 & 0 \\
\hline & I prefer not to say & 1.7 & 0 & 0 \\
\hline
\end{tabular}


regarding age, income, education level, marital status and ethnicity.

\subsubsection{Pathological Narcissism}

The French validated version (Diguer, Turmel, Luis Da Silva, \& Mathieu, 2014) of the Pathological Narcissism Inventory (PNI; Pincus, Ansell, Pimentel, Cain, Wright, \& Levy, 2009), a 52-item self-report questionnaire was used to measure multidimensional pathological narcissism. The inventory is composed of a 6-point scale ranging from 1 "Not at all like me" to 6 "Very much like me". The PNI measures narcissistic grandiosity (exploitativeness, grandiose fantasy, self-sacrificing self-enhancement) and narcissistic vulnerability (contingent self-esteem, entitlement rage, devaluing, hiding the self) (Wright, Lukowitsky, Pincus, \& Conroy, 2010). The seven-factor structure of the PNI was validated in a normal sample and a clinical sample (Pincus et al., 2009). Alpha coefficient for the seven PNI subscales ranged from 0.58 to 0.92 in the present sample.

\subsubsection{Explicit Self-Esteem}

The Rosenberg Self-Esteem Scale (RSES; Rosenberg, 1965) is a widely used 10-item measure of global selfesteem. The French version validated was used in this study (Vallières \& Vallerand, 1990). Responses range from 1 (strongly disagree) to 4 (strongly agree). A good internal consistency ( $\alpha=0.70$ à 0.90 ) was reported (Vallières \& Vallerand, 1990). Correlation for test-retest reliability was of .84 $(p<0.001)$ showing good temporal stability (Vallières \& Vallerand, 1990). The internal consistency of the RSES for the present study was 0.93.

\subsubsection{Implicit Self-Esteem}

Implicit self-esteem was assessed with the Implicit Association Test (Self-esteem IAT; Greenwald \& Farnham, 2000), a categorization task that measures automatic response latency between self-relevant and not-self-relevant words associated with pleasant and unpleasant words. We translated the IAT in French using a standard double translation procedure. Participants had to categorize words appearing in a random order as quickly and accurately as possible on a computer screen. Basically, they had to differentiate between pleasant and unpleasant word (e.g., joy, sunrise, torture, and death) or self and not-self words (e.g., I, me, he, and they). For the first trial, participants distinguished pleasant vs. unpleasant words and on the second trial, they distinguished self vs. not-self words. Then, pleasant and self words shared the same response key and unpleasant and not-self words shared another response key. Associating pleasant words to self words (congruent block) should be relatively easy for people with high self-esteem, thus their latency response should be shorter. On the contrary, when pleasant and not-self words (incongruent block) shared a response key and unpleasant and self shared another one, it should be harder for people with high self-esteem. Thus, latency should be longer. Implicit self-esteem was calculated by subtracting the mean scores of the incongruent block with the mean scores of the congruent block dividing by the inclusive standard deviation (Greenwald et al., 2003). Latency was calculated with the E-Prime 2.0 software. The IAT effect ( $D$ score) has a possible range of -2 to +2 and break points are based on Cohen's conventional criteria for effect size, i.e. "slight" $(0.15)$, "moderate" $(0.35)$ and "strong" $(0.65)$ (Cohen, 1988; Greenwald, Nosek, \& Banaji, 2003). In an effort to control for the apparition effect of the blocks, half of participants began by categorizing combined trials pleasant + self and the other half began by categorizing combined trials pleasant + not-self. Practice trials included 24 words and experimental trials included 48 words. When compared with other implicit measures, the IAT had the highest reliability (e.g. Bosson et al., 2008). The IAT also showed good construct validity (Bosson et al., 2008) and predictive validity (Greenwald, Poehlman, Uhlmann, \& Banaji, 2009).

\subsection{Statistical Analysis}

All analyses were performed using SPSS software version 20.0. To test our first objective, a multivariate analysis of variance (MANOVA) was conducted to compare the ED group, the ANX group and the HC group on narcissism and explicit self-esteem. An analysis of variance (ANOVA) was conducted for implicit self-esteem considering the absence of correlation between implicit self-esteem and explicit self-esteem and narcissism. Hochberg's GT2 post hoc test was used considering sample size's differences.

To test our second objective, Pearson correlation analysis (two-tail) was first computed between grandiose and vulnerable narcissism, explicit and implicit self-esteem for the three groups. Hierarchical multiple regression analyses were used to predict grandiose and vulnerable narcissism (dependant variables) with explicit 
self-esteem, implicit self-esteem and the interaction between explicit and implicit self-esteem as predictors (independent variables). All variables were standardised as recommended for the use of interaction terms. We added a categorical variable to account for group affiliation, i.e. belonging or not to ED group. This variable was called "ED group variable". Considering the presence of this variable (controlling for group pertaining (ED group or not)), all participants were then included in the regression analyses $(\mathrm{N}=197)$. The first block included all direct effects: implicit self-esteem, explicit self-esteem, and the ED group variable. The second block included three double interaction effects: implicit self-esteem $\times$ explicit self-esteem, explicit self-esteem $\times$ ED group variable, and implicit self-esteem $\times$ ED group variable. The third block included a triple interaction effect: explicit self-esteem $\times$ implicit self-esteem $\times$ ED group variable.

\section{Results}

\subsection{Group's Comparison}

Table 2 presents mean scores for grandiose and vulnerable narcissism as well as the seven subscales of the PNI, and explicit self-esteem and implicit self-esteem among the ED, ANX and HC groups. Results of the MANOVA revealed differences across groups on both grandiose narcissism $F(2,200)=3.90, p=0.022 ; d=0.40$ and vulnerable narcissism $F(2,200)=27.2, p<0.001 ; d=1.00$. Regarding grandiose narcissism, Hochberg's post hoc test showed that there were a difference between the ED group and the HC group, but not between the ED group and the ANX group. As expected, ED patients had the highest level of grandiose narcissism, and the HC group had the lowest level of grandiose narcissism. For vulnerable narcissism, Hochberg's post hoc test showed significant difference between each group. The ED group presented the highest level of vulnerable narcissism, followed by the ANX group and by the HC group. More precisely, results suggested that the ED group had significantly higher score than the HC group (Table 2) on all the subscales, except on the exploitativeness subscale $(p=$ 0.31). When comparing the ED group with the ANX group, only the contingent self-esteem subscale could discriminate between the ED and ANX groups. For this subscale, the three groups had significantly different levels and ED group had the highest levels of contingent self-esteem.

In addition, results indicated significant differences across the three groups on explicit self-esteem $F(2,201)=$ 88.58, $p<0.001 ; d=-1.94$. As expected, the ED group had the lowest levels of explicit self-esteem compared to the ANX and HC groups. The ANX group had lower levels of explicit self-esteem than the HC group.

Table 2. Means (SD) of the explicit self-esteem, implicit self-esteem and grandiose and vulnerable narcissism subscales for the ED group, the ANX group and the HC group.

\begin{tabular}{|c|c|c|c|c|}
\hline & \multicolumn{3}{|c|}{ Groups } & \multirow[b]{2}{*}{ Group $F$} \\
\hline & ED & ANX & $\mathrm{HC}$ & \\
\hline Grandiose Narcissism & $3.27^{\mathrm{a}}(0.68)$ & $3.08^{\mathrm{ab}}(0.79)$ & $2.95^{\mathrm{b}}(0.61)$ & $3.9^{*}$ \\
\hline Exploitativeness & $3.02^{\mathrm{a}}(0.83)$ & $2.77^{\mathrm{a}}(1.0)$ & $2.92^{\mathrm{a}}(0.74)$ & 1.19 \\
\hline Grandiose Fantasy & $3.12^{\mathrm{a}}(0.98)$ & $3.12^{\mathrm{a}}(1.1)$ & $2.68^{\mathrm{b}}(0.89)$ & $4.93^{* *}$ \\
\hline Self-Sacrificing Self-Enhancement & $3.67^{\mathrm{a}}(0.92)$ & $3.35^{\mathrm{ab}}(0.87)$ & $3.24^{\mathrm{b}}(0.79)$ & $4.46^{*}$ \\
\hline Vulnerable Narcissism & $3.39^{\mathrm{a}}(0.75)$ & $2.96^{\mathrm{b}}(0.75)$ & $2.52^{\mathrm{c}}(0.68)$ & $27.2^{* *}$ \\
\hline Contingent Self-Esteem & $3.78^{\mathrm{a}}(0.98)$ & $2.97^{\mathrm{b}}(0.95)$ & $2.48^{\mathrm{c}}(0.82)$ & $37.23^{* * *}$ \\
\hline Entitlement Rage & $2.84^{\mathrm{a}}(0.98)$ & $2.63^{\mathrm{ab}}(0.93)$ & $2.34^{\mathrm{b}}(0.74)$ & $6.16^{* *}$ \\
\hline Devaluing & $3.05^{\mathrm{a}}(0.93)$ & $2.80^{\mathrm{a}}(0.96)$ & $2.28^{\mathrm{b}}(0.85)$ & $14.06^{* *}$ \\
\hline Hiding the Self & $3.88^{\mathrm{a}}(0.99)$ & $3.47^{\mathrm{a}}(1.13)$ & $2.94^{\mathrm{b}}(0.92)$ & $16.2^{* *}$ \\
\hline Explicit Self-Esteem & $23.73^{\mathrm{a}}(5.57)$ & $30.75^{\mathrm{b}}(5.34)$ & $34.31^{\mathrm{c}}(3.88)$ & $88.58^{* *}$ \\
\hline Implicit Self-Esteem & $0.33^{\mathrm{a}}(0.28)$ & $0.36^{\mathrm{a}}(0.28)$ & $0.40^{\mathrm{a}}(0.25)$ & 1.32 \\
\hline
\end{tabular}

Note: Means with different letters in their superscripts differ at the 0.05 or better. ED = eating disordered group, ANX = psychiatric control group who suffer from anxiety disorders, $\mathrm{HC}=$ healthy control group. ${ }^{*} p \leq 0.05 .^{* *} p \leq 0.01$. 
Contrary to our hypotheses, no significant differences were found for the implicit self-esteem between groups, $F(2,205)=1.32, p=0.271 ; d=-0.21$. However, according to Cohen's (1988) convention criteria of the effect size, the ED group was characterised by low implicit self-esteem and the two control groups were characterised by moderate implicit self-esteem.

\subsection{Link between Pathological Narcissism and Self-Esteem}

Chi-square tests were used to compare whether the strength of the associations between all variables were different according to group (ED, ANX, HC) and no significant differences were found which means that the three groups did not differ with regards to their relationship between narcissism and self-esteem. Tables 3-5 present correlations between narcissism and self-esteem for each group.

More precisely, no significant association was found between grandiose narcissism and explicit self-esteem for the ED and HC groups. Vulnerable narcissism was significantly and negatively associated with explicit selfesteem for all the groups, which means that higher vulnerable narcissism is related to lower explicit self-esteem. No significant association was found between narcissism, either in the grandiose or vulnerable phenotypes, with implicit self-esteem for the three groups.

Hierarchical multiple regressions were performed to predict grandiose and vulnerable narcissism according to explicit self-esteem, implicit self-esteem, the interaction between self-esteem facets, and the ED group variable. For grandiose narcissism, when the three blocks were entered, only the first block was significant $(F=2.82, p=$ 0.04) and no predictor was significant. We then removed the third block, which was not significant, to examine the contribution of the two first block: 1) the direct effects (implicit self-esteem, explicit self-esteem, and the ED group variable) and 2) the double interaction effects (implicit self-esteem $\times$ explicit self-esteem, explicit selfesteem $\times$ ED group variable, and implicit self-esteem $\times$ ED group variable), but no predictor was significant (all $p>0.05$ ). We then entered the first block only, but still no predictor was significant (all $p>0.05$ ).

For vulnerable narcissism, the regression model was significant $(F=12.53, p>0.001)$ when the three blocks

Table 3. Pearson correlations for self-esteem and narcissism in the ED group.

\begin{tabular}{ccccc}
\hline & Explicit Self-Esteem & $\begin{array}{c}\text { Implicit } \\
\text { Self-Esteem }\end{array}$ & $\begin{array}{c}\text { Grandiose } \\
\text { Narcissism }\end{array}$ & $\begin{array}{c}\text { Vulnerable } \\
\text { Narcissism }\end{array}$ \\
\hline Explicit Self-Esteem & 1 & 0.026 & -0.027 & $-0.389^{* *}$ \\
Implicit Self-Esteem & 0.026 & 1 & 0.053 & 0.073 \\
Grandiose Narcissism & -0.027 & 0.053 & 1 & $0.668^{* *}$ \\
Vulnerable Narcissism & $-0.389^{* *}$ & 0.073 & $0.668^{* *}$ & 1 \\
\hline
\end{tabular}

Table 4. Pearson correlations for self-esteem and narcissism in the ANX group.

\begin{tabular}{cccc}
\hline & Explicit Self-Esteem & $\begin{array}{c}\text { Implicit } \\
\text { Self-Esteem }\end{array}$ & $\begin{array}{c}\text { Grandiose } \\
\text { Narcissism } \\
\text { Explicit Self-Esteem }\end{array}$ \\
Implicit Self-Esteem & 1 & 0.169 & $-0.308^{*}$ \\
Narcissism & 1 & -0.009 & $-0.535^{* *}$ \\
Grandiose Narcissism & 0.169 & 0.009 & 1 \\
Vulnerable Narcissism & $-0.308^{*}$ & -0.188 & 0.188 \\
\hline
\end{tabular}

Table 5. Pearson correlations for self-esteem and narcissism in the HC group.

\begin{tabular}{cccc} 
& Explicit Self-Esteem & $\begin{array}{c}\text { Implicit } \\
\text { Self-Esteem }\end{array}$ & $\begin{array}{c}\text { Grandiose } \\
\text { Narcissism }\end{array}$ \\
\hline Explicit Self-Esteem & 1 & $0.264^{*}$ & -0.109 \\
Narcissism & 1 & -0.030 \\
Implicit Self-Esteem & $0.264^{*}$ & -0.030 & 1 \\
Grandiose Narcissism & -0.109 & -0.192 & 0.192 \\
Vulnerable Narcissism & $-0.413^{* *}$ & 1 \\
\hline
\end{tabular}


were entered. Considering that when the three blocks were entered, no predictor from the third block was significant and that only explicit self-esteem was found significant $(\beta=-0.562, t[197]=-5.82, p<0.001)$, we then removed the third block. We examine the contribution of the two first block: 1 ) the direct effects (implicit self-esteem, explicit self-esteem, and the ED group variable) and 2) the double interaction effects (implicit self-esteem $\times$ explicit self-esteem, explicit self-esteem $\times$ ED group variable, and implicit self-esteem $\times$ ED group variable) and still only the explicit self-esteem predictor was significant $(p>0.001)$. We then only entered the first block and explicit self-esteem was the only significant predictor $(p>0.001)$.

Lower levels of explicit self-esteem predict higher levels of vulnerable narcissism among all the participants in the study.

\section{Discussion}

The aims of the present study were twofold: First, we compared levels of grandiose and vulnerable narcissism and explicit and implicit self-esteem among an ED, ANX and HC groups. Second, we explored the role of the two facets of self-esteem when predicting grandiose and vulnerable narcissism.

In general, results of the present study indicated that higher levels of grandiose and vulnerable narcissism, as well as lower levels of explicit self-esteem characterized EDs. No significant differences were found for implicit self-esteem. The examination of the role of explicit and implicit self-esteem when predicting grandiose or vulnerable narcissism did not confirm that discrepant self-esteem (low or high) could predict grandiose or vulnerable narcissism. Only explicit self-esteem was a reliable predictor of vulnerable narcissism.

\subsection{Pathological Narcissism in ED Patients}

ED patients expressed higher levels of pathological narcissism, both grandiose and vulnerable narcissism compared to women with no psychiatric disorders. This was concordant with previous research on one-dimensional narcissism (Steiger, Jabalpurwala, Champagne, \& Stotland, 1997). However, by assessing narcissism using the PNI, which captures both grandiose and vulnerable narcissism, our results underlined the important contribution of the narcissistic vulnerability in EDs. Indeed, narcissistic vulnerability is the only phenotype that differentiated ED patients from those with anxiety disorder. Considering that EDs is highly comorbid with anxiety disorders, we may suppose that vulnerable narcissism is clearly associated with eating pathology. Vulnerable narcissism refers to concern with approval of others (Cooper \& Maxwell, 1995; Pimentel et al., 2006). It implies hiding aspects of the self that seems needy or inadequate and also experiencing fluctuations in self-esteem contingent on external sources of admiration (Roche, Pincus, Lukowitsky, Ménard, \& Conroy, 2013). Vulnerable narcissism is positively associated with more internalized problems like affect regulation, dysphoria, anxiety and shame (Pincus et al., 2009; Tritt, Ryder, Ring, \& Pincus, 2010).

More specifically, the subscale "contingent self-esteem", which refers to the dysregulation of self-esteem in the absence of external sources of admiration and recognition, was significantly higher in the ED group compared to ANX group and HC group. Statements like: "When others don't notice me, I start to feel worthless" or "It's hard to feel good about myself unless I know other people admire me" were significantly more endorsed by ED patients. They appeared to be deeply insecure and in need of others in order to feel good about themselves. We may think that, for ED patients, the overinvestment of shape, weight and body might be a way to obtain external validation and admiration considering their particularly sensitivity to external reinforcement. Indeed, earlier work from Johnson and Connors (1987) described a category of ED patients, labeled as the false self/narcissists, which were characterised by an attempt to "compensate for or hide interoceptive deficits" (p. 114).

\subsection{Self-Esteem in ED Patients}

ED patients showed low levels of both explicit and implicit self-esteem, which suppose a convergent low self-esteem. It seems that at an unconscious and conscious level, ED patients showed an impaired self-worth. Our findings were also in line with clinical conceptualisations of EDs as a symptom of chronic low self-esteem (Silverstone, 1992) and with current cognitive models of EDs (Fairburn, Cooper, \& Shafran, 2003). These models proposed that the negative self-evaluation is central in the maintenance of eating pathology since women who suffer from EDs tend to largely overcontrol their eating, weight or shape in order to compensate for their negative self-evaluation. 
Although the convergent low self-esteem found in the present study does not support findings from Cokerham's study (2009), it thus supports results obtained by Vanderlinden and colleagues (2009). Sample selection might explain in part those differences; Cockerham and colleagues (2009) only included patients with bulimia and binge eating disorders, whereas Vanderlinden and colleagues (2009) included all EDs diagnosis as for us. Convergent low self-esteem was also observed among other psychiatric population. For example, lower levels of explicitand implicit self-esteem were found among individuals who suffer from body dysmorphic disorder when compared to healthy controls (Buhlman, Teachman, Naumann, Fehlinger, \& Rief, 2009). Likewise, lower implicit and explicit self-esteem were found among current depressive patients compared to healthy controls (Risch et al., 2010). These findings showed that both explicit and implicit self-esteem are impaired; supporting cognitive theories that suggests that negative self-evaluation is playing an important role in the development and maintenance of psychiatric problems.

\subsection{Link between Self-Esteem and Pathological Narcissism}

Our findings did not support the mask model of narcissism that postulated that narcissism is characterised by the interaction of high levels of explicit self-esteem and low levels of implicit self-esteem. Theoretically, this model is incompatible with the picture found among psychiatric population since those patients rather experience lower explicit self-esteem. Despite this, no discrepancy between the two facets of self-esteem was found and consequently, no interaction effect could predict either grandiose or vulnerable narcissism. Only explicit self-esteem was strongly linked with vulnerable narcissism. Our results are in accordance with those obtained from the meta-analysis of Bosson and colleagues (2008) who concluded that no relationship was found between implicit measures and narcissism as well as no evidence of an interaction effect between explicit and implicit self-esteem when predicting narcissism. Thus, even if we specified the construct of narcissism by distinguishing both phenotypes, the contribution of implicit self-esteem in the explanation of narcissism is still weak.

\subsection{Limitations and Implications for Future Studies}

Some limitations of the present study should be noted. First, the cross-sectional design used in the present study unable us to examine fluctuations in self-esteem over time; self-esteem has rather been conceptualized as a fixed and stable variable. Preliminary evidence suggested that pathological narcissism is related to fluctuations of self-esteem, especially when linked to perceived social threats (Besser \& Zeigler-Hill, 2010; Besser \& Priel, 2010; Fetterman \& Robinson, 2010; Morf \& Rhodewalt, 2001; Zeigler-Hill, Myers, \& Clark, 2010). A longitudinal study design would have captured the complexity of this relationship. Also, the correlational design of this study means that causal conclusions cannot be drawn.

The fact that no significant difference was found between implicit self-esteem across the ED group and the HC group was unexpected. ED patients had lower levels of implicit than HC participants, but the difference was not significant. This raises the question about the validity of the IAT. Criticisms had also been made on the words used in the IAT as being too general and neutral. According to the recent agency model of narcissism (Campbell, Brunell, \& Finkel, 2006; Campbell \& Foster, 2007; Campbell \& Green, 2008), narcissism is associated with positive self-views on agentic domains like status and intelligence rather than with communal domains like kindness and nurturing as measured in the present study. Campbell and his colleagues (2009) proposed that narcissism reflects positive self-views in agentic domains, combined with negative self-views on communal domains. The agentic model appeared to be an interesting avenue for future research.

Despite the limitations mentioned above, the current study supports that patients with EDs suffered from low self-esteem and, they possessed high levels of narcissism, especially vulnerable narcissism. ED patients are thus characterised by a deep fragile sense of self, which they are trying to hide and they are constantly in need of others to validate and admire them. These aspects of their personality should be taken into account in models and treatments of EDs. Discussion around the difficulties patients experience in giving themselves positive feedback or their sensitivity to feedback is important for long-term recovery.

\section{Acknowledgements}

We would like to thank all the team members of the Eating Disorders Unit at Centre Hospitalier de l'Université Laval (CHUL) for their help during the recruitment period. We would also like to thank E. Gosselin for her as- 
sistance in data entry and $\mathrm{H}$. Paradis for her advice regarding statistical analysis.

This research project was not funded. All the authors declare no potential or actual conflict of interest.

\section{References}

Akhtar, S., \& Thomson, J. A. (1982). Overview: Narcissistic Personality Disorder. American Journal of Psychiatry, 139, 1220. http://dx.doi.org/10.1176/ajp.139.1.12

Besser, A., \& Priel, B. (2010). Personality Vulnerability, Low Social Support, and Maladaptive Cognitive Emotion Regulation under Ongoing Exposure to Terrorist Attacks. Journal of Social and Clinical Psychology, 29, 166-201. http://dx.doi.org/10.1521/jscp.2010.29.2.166

Besser, A., \& Zeigler-Hill, V. (2010). The Influence of Pathological Narcissism on Emotional and Motivational Responses to Negative Events: The Roles of Visibility and Concern about Humiliation. Journal of Research in Personality, 44, 520-534. http://dx.doi.org/10.1016/j.jrp.2010.06.006

Bosson, J. K., \& Prewitt-Freilino, J. L. (2007). Overvalued and Ashamed: Considering the Roles of Self-Esteem and SelfConscious Emotions in Covert Narcissism. In J. L. Tracy, R. W. Robins, \& J. P. Tangney (Eds.), The Self-Conscious Emotions: Theory and Research (2nd ed., pp. 407-425). New York, NY: Guilford.

Bosson, J. K., Lakey, C. E., Campbell, W. K., Zeigler-Hill, V., Jordan, C. H., \& Kernis, M. H. (2008). Untangling the Links between Narcissism and Self-Esteem: A Theoretical and Empirical Review. Social and Personality Psychology Compass, 2, 1415-1439. http://dx.doi.org/10.1111/j.1751-9004.2008.00089.x

Brown, R. P., \& Bosson, J. K. (2001). Narcissus Meets Sisyphus : Self-Love, Self-Loathing, and the Never-Ending Pursuit of Self-Worth. Psychological Inquiry, 12, 210-213.

Brunton, N. J., Lacey, H. J., \& Waller, H. G. (2005). Narcissism and Eating Characteristics in Young Nonclinical Women. The Journal of Nervous and Mental Disease, 193, 140-143. http://dx.doi.org/10.1097/01.nmd.0000152784.01448.fe

Buhlmann, U., Teachman, B., Gerbershagen, A., Kikul, J., \& Rief, W. (2008). Implicit and Explicit Self-Esteem and Attractiveness Beliefs among Individuals with Body Dysmorphic Disorder. Cognitive Therapy and Research, 32, $213-225$. http://dx.doi.org/10.1007/s10608-006-9095-9

Campbell, K. W. \& Foster, J. D. (2007). The Narcissistic Self: Background, an Extended Agency Model, and Ongoing Controversies. In C. Sedikides, \& S. Spencer (Eds.), The Self (p. 115-138). New York: Psychology Press.

Campbell, K. W. \& Green, J. D. (2007). Narcissism and Interpersonal Self-Regulation. In J. V. Wood, A. Tesser, \& J. G. Holmes (Eds.), The Self and Social Relationships (pp. 73-94). New York: Psychology Press.

Campbell, K. W., Bosson, J. K., Goheen, T. W., Lakey, C. E., \& Kernis, M. H. (2007). Do Narcissists Dislike Themselves “Deep Down Inside”? Psychological Science, 18, 227-229. http://dx.doi.org/10.1111/j.1467-9280.2007.01880.x

Campbell, K. W., Brunell, A. B., \& Finkel, E. J. (2006). Narcissism, Interpersonal Self-Regulation and Romantic Relationships: An Agency Model Approach. In K. D. Vohs, \& E. J. Finkel (Eds.), Self and Relationships: Connecting Intrapersonal and Interpersonal Processes (pp. 57-83). New York: The Guilford Press.

Cockerham, E., Stopa, L., Bell, L., \& Gregg, A. (2009). Implicit Self-Esteem in Bulimia Nervosa. Journal of Behavior Therapy and Experimental Psychiatry, 40, 265-273. http://dx.doi.org/10.1016/j.jbtep.2008.12.003

Cohen, J. (1988). Statistical Power Analysis for the Behavioral Sciences (2nd ed.). Hillsdale, NJ: Lawrence Erlbaum Associates.

Cooper, J., \& Maxwell, N. (1995). Narcissistic Wounds. London: Jason Aronson.

De Jong, P. J. (2002). Implicit Self-Esteem and Social Anxiety: Differential Self-Favouring Effects in High and Low Anxious Individuals. Behaviour Research and Therapy, 40, 501-508. http://www.ncbi.nlm.nih.gov/pubmed/12038643 http://dx.doi.org/10.1016/S0005-7967(01)00022-5

De Raedt, R., Schacht, R., Franck, E., \& De Houwer, J. (2006). Self-Esteem and Depression Revisited: Implicit Positive Self-Esteem in Depressed Patients? Behaviour Research and Therapy, 44, 1017-1028.

http://dx.doi.org/10.1016/j.brat.2005.08.003

Diguer, L., Turmel, V., Luis Da Silva, R., \& Mathieu, V. (2014). Development and Initial Structure Analysis of a French version of the Pathological Narcissism Inventory. Poster Session Presented at the Meeting of the European Psychiatric Association, Munich, 1-4 March 2014.

Fairburn, C. G., Cooper, Z., \& Shafran, R. (2003). Cognitive Behaviour Therapy for Eating Disorders: A “Transdiagnostic” Theory and Treatment. Behaviour Research and Therapy, 41, 509-528. http://dx.doi.org/10.1016/S0005-7967(02)00088-8

Fetterman, A. K., \& Robinson, M. D. (2010). Contingent Self-Importance among Pathological Narcissists: Evidence from an Implicit Task. Journal of Research in Personality, 44, 691-697. http://dx.doi.org/10.1016/j.jrp.2010.09.002

Gemar, M. C., Segal, Z. V., Sagrati, S., \& Kennedy, S. J. (2001). Mood-Induced Changes on the Implicit Association Test in 
Recovered Depressed Patients. Journal of Abnormal Psychology, 110, 282-289. http://dx.doi.org/10.1037/0021-843X.110.2.282

Gordon, K. H., \& Dombeck, J. J. (2010). The Associations between Two Facets of Narcissism and Eating Disorder Symptoms. Eating Behaviors, 11, 288-292. http://dx.doi.org/10.1016/j.eatbeh.2010.08.004

Greenwald, A. G., \& Farnham, S. D. (2000). Using the Implicit Association Test to Measure Self-Esteem and Self-Concept. Journal of Personality and Social Psychology, 79, 1022-1038. http://dx.doi.org/10.1037/0022-3514.79.6.1022

Greenwald, A. G., Nosek, B. A., \& Banaji, M. R. (2003). Understanding and Using the Implicit Association Test: I. An Improved Scoring Algorithm. Journal of Personality and Social Psychology, 85, 197-216. http://dx.doi.org/10.1037/0022-3514.85.2.197

Greenwald, A. G., Poehlman, T. A., Uhlmann, E. L., \& Banaji, M. R. (2009). Understanding and Using the Implicit Association Test: III. Meta-Analysis of Predictive Validity. Journal of Personality and Social Psychology, 97, 17-41. http://dx.doi.org/10.1037/a0015575

Gregg, A. P., \& Sedikides, C. (2010). Narcissistic Fragility: Rethinking Its Links to Explicit and Implicit Self-Esteem. Self and Identity, 9, 142-161. http://dx.doi.org/10.1080/15298860902815451

Holliday, J., Uher, R., Landau, S., Collier, D., \& Treasure, J. (2006). Personality Pathology among Individuals with a Lifetime History of Anorexia Nervosa. Journal of Personality Disorders, 20, 417-430. http://dx.doi.org/10.1521/pedi.2006.20.4.417

Horowitz, M. (2013). Prototypical Formulation of Pathological Narcissism. In J. S. Ogrodniczuk (Ed.), Understanding and Treating Pathological Narcissism (pp. 81-92). Washington DC: American Psychological Association. http://dx.doi.org/10.1037/14041-005

Horvath, S., \& Morf, C. C. (2010). To Be Grandiose or Not to Be Worthless: Different Routes to Self-Enhancement for Narcissism and Self-Esteem. Journal of Research in Personality, 44, 585-592. http://dx.doi.org/10.1016/j.jrp.2010.07.002

Jacobi, C., Hayward, C., de Zwaan, M., Kraemer, H. C., \& Agras, W. S. (2004). Coming to Terms with Risk Factors for Eating Disorders: Application of Risk Terminology and Suggestions for General Taxonomy. Psychological Bulletin, 130, 19-65. http://dx.doi.org/10.1037/0033-2909.130.1.19

Johnson, C., \& Connors, M. E. (1987). The Etiology and Treatment of Bulimia Nervosa. New York: Basic Books.

Jordan, C. H., Spencer, S. J., Zanna, M. P., Hoshino-Browne, E., \& Correll, J. (2003). Secure and Defensive High Self-Esteem. Journal of Personality and Social Psychology, 85, 969-978. http://dx.doi.org/10.1037/0022-3514.85.5.969

Kernberg, O. (1966). Structural Derivatives of Object Relationships. The International Journal of Psycho-Analysis, 47, 236253.

Kernberg, O. (1975). Borderline Conditions and Pathological Narcissism. New York: Jason Aronson.

Kohut, H., \& Wolf, E. S. (1986). The Disorders of Self and Their Treatment: An Outline. In A. P. Morrison (Ed.), Essential Papers on Narcissism (pp. 175-196). New York and London: New York University Press.

Lehoux, P., Steiger, H., \& Jabalpurwala, S. (2000). State/Trait Distinctions in Bulimic Syndromes. International Journal of Eating Disorders, 27, 36-42. http://dx.doi.org/10.1002/(SICI)1098-108X(200001)27:1<36::AID-EAT4>3.0.CO;2-U

Meijboom, A., Jansen, A., Kampman, M., \& Schouten, E. (1999). An Experimental Test of the Relationship between SelfEsteem and Concern about Body Shape and Weight in Restrained Eaters. International Journal of Eating Disorders, 25, 327-334. http://dx.doi.org/10.1002/(SICI)1098-108X(199904)25:3<327::AID-EAT11>3.0.CO;2-5

Miller, J. D., Hoffman, B. J., Gaughan, E. T., Gentile, B., Maples, J., \& Keith Campbell, W. (2011). Grandiose and Vulnerable Narcissism: A Nomological Network Analysis. Journal of Personality, 79, 1013-1042. http://dx.doi.org/10.1111/j.1467-6494.2010.00711.x

Morf, C. C., \& Rhodewalt, F. (2001). Unraveling the Paradoxes of Narcissism: A Dynamic Self-Regulatory Processing Model. Psychological Inquiry, 12, 177-196. http://dx.doi.org/10.1207/S15327965PLI1204_1

Pimentel, C. A., Ansell, E. B., Pincus, A. L., \& Cain, N. M. (2006). Initial Validation and Derivation of the Vulnerable Narcissism Scale. Unpublished Manuscript, University Park, PA: Pennsylvania State University.

Pincus, A. L., \& Lukowitsky, M. R. (2010). Pathological Narcissism and Narcissistic Personality Disorder. Annual Review of Clinical Psychology, 6, 421-446. http://dx.doi.org/10.1146/annurev.clinpsy.121208.131215

Pincus, A. L., Ansell, E. B., Pimentel, C., Cain, N. M., Wright, A. G. C., \& Levy, K. N. (2009). Initial Construction and Validation of the Pathological Narcissism Inventory. Psychological Assessment, 21, 365-379.

http://dx.doi.org/10.1037/a0016530

Raskin, R. N., \& Hall, C. S. (1979). A Narcissistic Personality Inventory. Psychological Reports, 45, 590. http://dx.doi.org/10.2466/pr0.1979.45.2.590

Raskin, R. N., \& Hall, C. S. (1981). The Narcissistic Personality Inventory: Alternative form Reliability and Further Evi- 
dence of Construct Validity. Journal of Personality and Social Psychology, 45, 159-162. http://dx.doi.org/10.1207/s15327752jpa4502_10

Risch, A. K., Buba, A., Birk, U., Morina, N., Steffens, M. C., \& Stangier, U. (2010). Implicit Self-Esteem in Recurrently Depressed Patients. Journal of Behavior Therapy and Experimental Psychiatry, 41, 199-206. http://dx.doi.org/10.1016/j.jbtep.2010.01.003

Roche, M. J., Pincus, A. L., Lukowitsky, M. R., Ménard, K. S., \& Conroy, D. E. (2013). An Integrative Approach to the Assessment of Narcissism. Journal of Personality Assessment, 95, 237-248. http://dx.doi.org/10.1080/00223891.2013.770400

Rosenberg, M. (1965). Society and the Adolescent Self-Image. Princeton, NJ: Princeton University Press.

Sheehan, D. V., Lecrubier, Y., Sheehan, K. H., Amorim, P., Janavs, J., Weiller, E., et al. (1998). The Mini-International Neuropsychiatric Interview (M.I.N.I): The Development and Validation of a Structured Diagnostic Psychiatric Interview for DSM-IV and ICD-10. Journal of Clinical Psychiatry, 59, 22-33.

Silverstone, P. H. (1992). Is Chronic Low Self-Esteem Disorders ? Medical Hypotheses, 39, 311-315. http://dx.doi.org/10.1016/0306-9877(92)90054-G

Steiger, H., Jabalpurwala, S., Champagne, J., \& Stotland, S. (1997). A Controlled Study of Trait Narcissism in Anorexia and Bulimia Nervosa. International Journal of Eating Disorders, 22, 173-178. http://dx.doi.org/10.1002/(SICI)1098-108X(199709)22:2<173::AID-EAT9>3.0.CO;2-C

Tritt, S., Ryder, A. G., Ring, A., \& Pincus, A. L. (2010). Pathological Narcissism and the Depressive Temperament. Journal of Affective Disorders, 122, 208-284. http://dx.doi.org/10.1016/j.jad.2009.09.006

Vallières, E. F., \& Vallerand, R. J. (1990). Traduction et validation anadienne-française de l'échelle de l'estime de soi de Rosenberg. International Journal of Psychology, 25, 305-316. http://dx.doi.org/10.1080/00207599008247865

Vanderlinden, J., Kamphuis, J. H., Slagmolen, C., Wigboldus, D., Pieters, G., \& Probst, M. (2009). Be Kind to Your Eating Disorder Patients : The Impact of Positive and Negative Feedback on the Explicit and Implicit Self-Esteem of Female Patients with Eating Disorders. Eating Weight Disorders, 14, 237-242. http://dx.doi.org/10.1007/BF03325124

Vater, A., Ritter, K., Schröder-Abé, M., Schütz, A., Lammers, C.-H., Bosson, J. K., \& Roepke, S. (2013). When Grandiosity and Vulnerability Collide: Implicit and Explicit Self-Esteem in Patients with Narcissistic Personality Disorder. Journal of Behavior Therapy and Experimental Psychiatry, 44, 37-47. http://dx.doi.org/10.1016/j.jbtep.2012.07.001

Wright, A. G. C., Lukowitsky, M. R., Pincus, A. L., \& Conroy, D. E. (2010). The Higher Order Factor Structure and Gender Invariance of the Pathological Narcissism Inventory. Assessment, 17, 467-483. http://dx.doi.org/10.1177/1073191110373227

Zeigler-Hill, V. (2006). Discrepancies between Implicit and Explicit Self-Esteem: Implications for Narcissism and Self-Esteem Instability. Journal of Personality, 74, 119-144. http://dx.doi.org/10.1111/j.1467-6494.2005.00371.x

Zeigler-Hill, V., Myers, E. M., \& Clark, C. B. (2010). Narcissism and Self-Esteem Reactivity: The Role of Negative Achievement Events. Journal of Research in Personality, 44, 285-292. http://dx.doi.org/10.1016/j.jrp.2010.02.005 


\section{Appendixes}

\section{ENP (Pincus et al., 2009)}

Veuillez évaluer dans quelle mesure vous vous reconnaissez dans chacun des énoncés suivants.

\begin{tabular}{ccccc}
\hline 1 & 2 & 3 & 4 & \\
$\begin{array}{c}\text { Je ne suis vraiment pas } \\
\text { comme cela }\end{array}$ & $\begin{array}{c}\text { Je ne suis pas comme } \\
\text { cela }\end{array}$ & $\begin{array}{c}\text { Je ne suis pas } \\
\text { vraiment comme cela }\end{array}$ & $\begin{array}{c}\text { Je suis un peu } \\
\text { comme cela }\end{array}$ & \begin{tabular}{c} 
Je suis comme cela \\
\hline
\end{tabular} \\
\hline
\end{tabular}

1. Il m'arrive souvent d'imaginer qu'on m'admire et qu'on me respecte.

2. Mon estime de soi varie beaucoup.

3. J'ai parfois honte d'avoir cru en des personnes qui finissent par me décevoir.

4. Je peux me sortir de toute situation en discutant avec les autres.

5. Quand je suis seul, j’ai de la difficulté à m’apprécier et à être content de moi.

6. Je me sens bien lorsque je m'occupe des autres.

7. Je déteste demander de l'aide.

8. Je ne me sens pas bien lorsque les autres ne me prêtent pas attention.

9. Je cache souvent mes besoins par peur que les autres pensent que je suis dépendant et dans le besoin.

10. Je peux faire croire n'importe quoi à n'importe qui.

11. Je deviens furieux lorsque les autres ne remarquent pas tout ce que je fais pour eux.

12. Cela me fâche quand les gens ne sont pas intéressés par ce que je dis ou ce que je fais.

13. Je ne dévoilerais pas mes sentiments ou mes pensées intimes à quelqu'un que je n’admire pas.

14. Je m'imagine souvent avoir une très grande influence sur le monde qui m'entoure.

15. Je trouve qu'il est facile de manipuler les gens.

16. Lorsque les autres ne me remarquent pas, je me sens sans valeur.

17. Je mets parfois des personnes de côté quand j’ai peur qu'elles me déçoivent.

18. Je deviens habituellement très en colère lorsque je n'obtiens pas ce que je veux des autres.

19. Souvent, afin de me rassurer sur ma valeur personnelle, je m'entoure de personnes importantes.

20. Quand je rends service aux autres, je m'attends à ce qu'ils me rendent service en retour.

21. Quand les autres n’arrivent pas à satisfaire mes attentes, j’ai souvent honte d'avoir eu ces attentes.

22. Je me sens important lorsque les autres comptent sur moi.

23. Je peux lire dans les gens comme dans un livre.

24. Lorsque les autres me déçoivent, je me fâche souvent contre moi-même.

25. Je suis le meilleur, car je me sacrifie pour les autres.

26. Je rêve souvent d'accomplir des choses qui sont probablement au-delà de mes capacités ou de mes moyens.

27. Je mets parfois des personnes de côté parce que je crains qu'elles ne fassent pas ce que je veux qu'elles fassent.

28. Il est difficile de montrer aux autres les faiblesses que je ressens l’intérieur de moi.

29. Je me fâche lorsqu'on me critique.

30. Je trouve difficile de m’apprécier à moins de savoir que les autres m’admirent.

31. Je me plais souvent à m’imaginer que je suis récompensé pour mes efforts.

32. Je m'en fais parfois à l'idée que la plupart des gens ne s'intéressent pas à moi.

33. J'aime avoir des amis qui comptent sur moi, car cela me fait me sentir important.

34. Parfois j'évite certaines personnes parce que je crains qu'elles ne se rendent pas compte de tout ce que je fais pour elles. 


\section{Continued}

35. Tout le monde aime entendre mes histoires.

$\begin{array}{llllll}1 & 2 & 3 & 4 & 5 & 6\end{array}$

36. Je trouve difficile de m’apprécier à moins de me sentir apprécié par les autres.

$\begin{array}{llllll}1 & 2 & 3 & 4 & 5 & 6\end{array}$

37. Cela m'irrite lorsque les gens ne remarquent pas à quel point je suis une bonne personne.

$\begin{array}{llllll}1 & 2 & 3 & 4 & 5 & 6\end{array}$

38. Je ne serai jamais satisfait tant que je n’obtiendrai pas tout ce que je mérite.

$\begin{array}{llllll}1 & 2 & 3 & 4 & 5 & 6\end{array}$

39. À travers mes sacrifices, j'essaie de montrer à quel point je suis une bonne personne.

$\begin{array}{llllll}1 & 2 & 3 & 4 & 5 & 6\end{array}$

40. Cela me déçoit lorsque les autres ne me remarquent pas.

$\begin{array}{llllll}1 & 2 & 3 & 4 & 5 & 6\end{array}$

41. J'envie souvent les réussites des autres.

42. Je m’imagine souvent accomplir des actes héroïques.

43. J'aide les autres afin de prouver que je suis une bonne personne.

44. Il est important de montrer aux autres que je peux me débrouiller tout seul, même s'il m’arrive parfois de douter de moi.

45. J'imagine souvent des scénarios où je suis reconnu pour mes réalisations.

46. Je ne peux supporter l'idée d'avoir à compter sur les autres, parce que cela me fait me sentir faible.

$\begin{array}{llllll}1 & 2 & 3 & 4 & 5 & 6\end{array}$

$\begin{array}{llllll}1 & 2 & 3 & 4 & 5 & 6\end{array}$

$\begin{array}{llllll}1 & 2 & 3 & 4 & 5 & 6\end{array}$

$\begin{array}{llllll}1 & 2 & 3 & 4 & 5 & 6\end{array}$

$\begin{array}{llllll}1 & 2 & 3 & 4 & 5 & 6\end{array}$

$\begin{array}{llllll}1 & 2 & 3 & 4 & 5 & 6\end{array}$

47. J'ai de la difficulté à être satisfait de moi lorsque les autres ne réagissent pas comme je le souhaiterais.

$\begin{array}{llllll}1 & 2 & 3 & 4 & 5 & 6\end{array}$

48. J'ai besoin de la reconnaissance des autres.

$\begin{array}{llllll}1 & 2 & 3 & 4 & 5 & 6\end{array}$

49. J'aspire à être quelqu'un aux yeux du monde entier.

$\begin{array}{llllll}1 & 2 & 3 & 4 & 5 & 6\end{array}$

50. Lorsque les autres perçoivent mes besoins, j’ai honte et je me sens anxieux.

$\begin{array}{llllll}1 & 2 & 3 & 4 & 5 & 6\end{array}$

51. Parfois, j’aime mieux être seul que de ne pas obtenir tout ce que je veux des autres.

$\begin{array}{llllll}1 & 2 & 3 & 4 & 5 & 6\end{array}$

52. Je peux devenir vraiment fâché lorsque les autres sont en désaccord avec moi.

$\begin{array}{llllll}1 & 2 & 3 & 4 & 5 & 6\end{array}$

\section{PERCEPTION PERSONNEL}

Pour chacune des caractéristiques ou descriptions suivantes, indiquez à quel point chacune est vraie pour vous en encerclant le chiffre approprié.

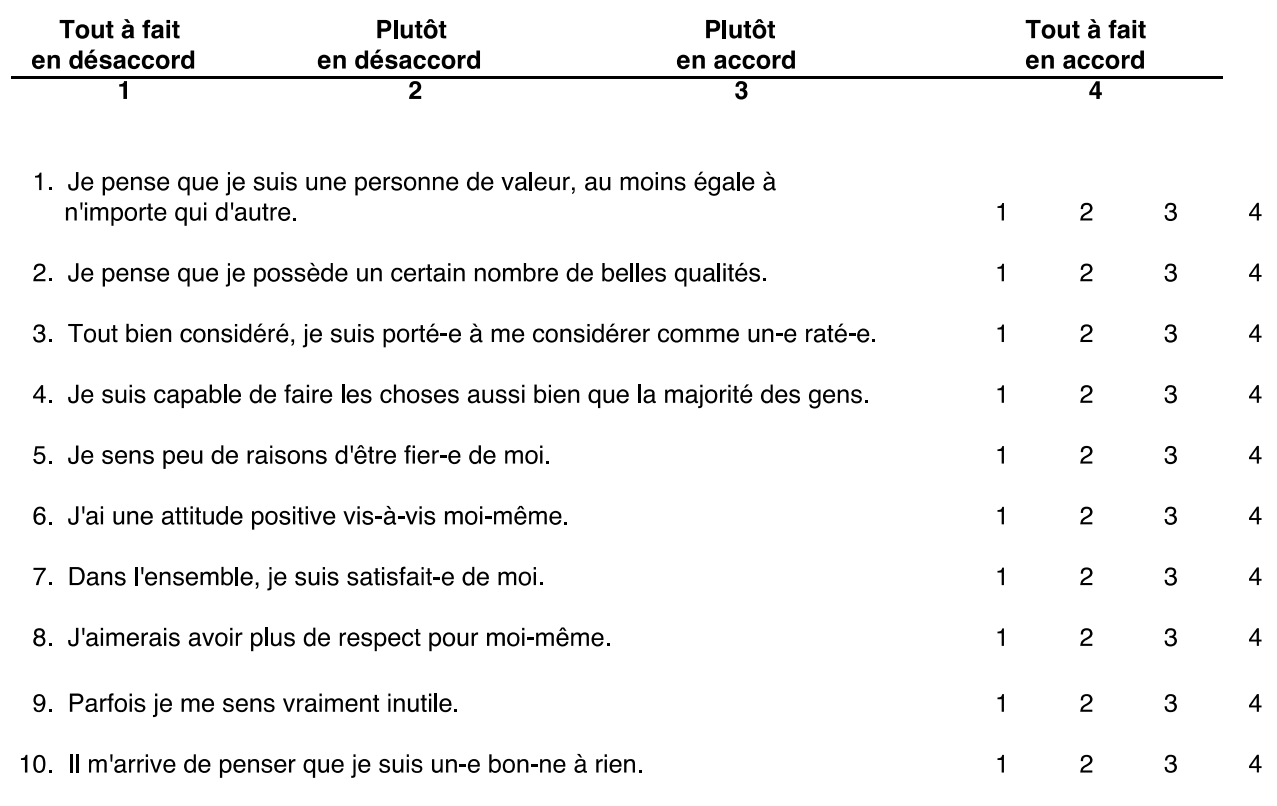

